\title{
THE INFLUENCE OF A DIFFERENT ACCOUNTING SYSTEM ON INFORMATIVE VALUE OF SELECTED FINANCIAL RATIOS*
}

\author{
Olga Malíková ${ }^{1}, Z_{\text {deněk Brabec }}^{2}$
}

\begin{abstract}
Faculty of Economics, Technical University of Liberec, Studentská 2, Liberec, Czech Republic E-mails: ${ }^{1}$ olga.malikova@tul.cz; ${ }^{2} z$ denek.brabec@tul.cz (corresponding author)
\end{abstract}

Received 09 May 2011; accepted 22 December 2011

\begin{abstract}
In recent global world the importance of financial markets is growing as well as the amount of capital distributed through these markets. To enable optimal efficiency of these markets the best investment opportunities has to be chosen. An alternative how to compare and select suitable companies to invest in is represented by a financial analysis of financial statements. The results of financial ratios are mainly influenced by the presumptions according to those the financial statements have been prepared. Therefore, in this article there is analysed if and eventually how significant the input data, influence the results of financial ratios. Firstly, the description of financial ratios that are used in following analysis is made. After that, there are analysed the requirements of Czech legislation and IAS/IFRS and their influence on financial statements. Then, the influence of five selected accounting transaction on balance sheets and income statements that are prepared once according to the Czech legislation and for the second time according to the IAS/IFRS is analysed. The final part tries to examine if and how strong the impact of different accounting system on the results of the selected financial ratios is.
\end{abstract}

Keywords: accounting system, financial accounting, financial analysis, financial ratios, financial statements.

Reference to this paper should be made as follows: Malíková, O.; Brabec, Z. 2012. The influence of a different accounting system on informative value of selected financial ratios, Technological and Economic Development of Economy 18(1): 149-163.

JEL Classification: M41, M48, G30.

\footnotetext{
* This article is worked up as the issue of the research project "Kritické komentáře k vybrané problematice teorie účetnictví a její aplikaci v podmínkách současné účetní regulace" (Critical comments to chosen problems of accounting theory and its application under the conditions of contemporary accounting regulation), which was realised on the Faculty of Economics at the Technical University of Liberec, in year 2010 with the financial support of the TUL in the frame of the competition for support of projects of specific university research.
} 


\section{Introduction}

In today's global world when the markets are more connected than ever before the information about the financial position and performance of the companies is becoming more important. If the capital providers want to choose into which company they should invest their resources, they need to compare the contemporary financial position and performance of selected companies and try to forecast their future development (Wahlen, Wieland 2011) (Lev et al. 2010). In the case of the listed companies, it could be helpful to use rating as an evaluative criterion of the successfulness of the selected companies (Užik, Šoltés 2009).

To enable the selection of the "right company" to invest in, the analysis and comparison of the possible candidates have to be made. The candidate companies could be estimated with the help of the financial analysis, especially through the comparison of selected financial ratios of these companies. The analysis with the help of financial ratios is suitable especially for external users of financial information because they don't have any access to the internal data of the company. So there has to be ensured that financial reporting grants "... a fair presentation of an organization's economic activities" (Ingram, Albright 2007: 22). It is necessary to keep in mind that the input data of the ratios are almost hard to compare. Major part of these input data comes namely from financial statements of the compared companies, which can use different form of disclosure and presentation of financial information in financial statements as well as they can prepare their financial statements according to different methods (De Franco et al. 2011). These differences exist basically even between the companies that prepare their financial statements within the frame of the same accounting system and they are larger when an international comparison is made because companies from various countries prepare in principle their financial statements according to a different accounting system (Alexander, Nobes 2004). Therefore, before the final selection of the best company is made the differences between these accounting systems and their influence on informative value of the selected financial ratios have to be carefully analysed.

This article would like to focus on the calculation of the financial ratios which are analyzed in terms of their input data. Especially, there are examined the effects of different accounting systems that influence these input data. In this regard, there is analysed if and eventually how significant the input data, which comes mainly from financial statements, influence the results of financial ratios. There will be compared financial ratios of a model Czech company, whereas once its financial statements will be prepared according to the Czech accounting legislation and for the second time according to the International Financial Reporting Standards (IFRS). IFRS is a new term for standards that have been published by International Accounting Standards Board (IASB) since the year 2002. Before that year the standards were entitled as International accounting standards (IAS). Since nowadays, besides IFRS, there are still some former valid IAS, in this text there is further used an abbreviation IAS/IFRS for these standards. At the beginning, there is made the description of four selected financial ratios that will be used for the following analysis. Then there will be highlighted the main differences between Czech accounting legislation and IAS/IFRS and then their influence will be judged on the balance sheet and income statement. After that a comparative analysis of recording of five selected accounting transactions according to the requirements of the selected accounting system will 
follow. The key differences in these requirements will be comprehensive demonstrated in the form of the balance sheet and income statement. The final part provides a synthesis of the results of four selected financial ratios, which are calculated on the basis of a different input data and there will be given some comments to the results of these ratios.

\section{Financial ratios}

This article is focused on financial ratios because these ratios "...provide a quick and relatively simple means of assessing the financial health of a business” (McLeaney, Atrill 2005: 206). These ratios are mostly used as a starting point for more detailed financial analysis because they can refer to the areas of good and bad performance as well as areas of significant changes, which should be analysed more carefully. Financial ratios could be also called accounting ratios (Nobes, Parker 2006: 654) because they describe the relationship between the certain items of financial statements. These ratios are very popular in practice namely for simplicity of their calculation and easy availability of input data. For the external users of financial statements financial ratios provide mostly the only way how to analyse the financial position and performance of the chosen company. They enable to compare the financial health and performance of companies in time series as well as between the chosen companies. To secure a high level of informative value of financial ratios that are calculated for different companies a presumption of homogeneity of compared companies is tacitly required (Kovanicová, Kovanic 1995).

For the following analysis there have been selected financial ratios of four main categories that are profitability, activity, liquidity and debt ratios. As there are more ratios in each group, in this article there will be calculated only one ratio of each group, which should be mostly able to demonstrate the influence of a different accounting system on the value of this ratio as well as should respect some simplification presumptions. Now a short description of four selected ratios that represents the above mentioned groups of financial ratios follows.

$$
\text { Return on capital employed }=\frac{\text { Earning before interest and taxes }(E B I T)}{\text { Capital employed }}(\text { Petř́k 2009: 228). }
$$

This ratio represents a fundamental measure of business performance. It expresses the relationship between the profit generated from operating activities and the capital invested into the company. The elimination of both interest and taxes from the profit figure should ensure better comparability or this ratio between different companies because the result of this ratio is not influenced by capital structure of the company as well as by taxation in various countries. Capital employed could include various groups of equity and liabilities, which depends on the purpose for that the performance should be analysed. In this text there is used the broadest form of this ratio, so from EBIT there are excluded all interest expenses and capital employed incorporates total equity and liabilities. The higher the result of this ratio is calculated, the better the performance of the company is achieved.

$$
\text { Asset turnover ratio }=\frac{\text { Sales }}{\text { Total assets }}(\text { Vance 2002: 23). }
$$


This ratio examines how effectively the assets of the company are being used to generate sales revenues. A higher asset turnover is preferred to a lower one, which means that the assets are being used more productively. This ratio is indirectly connected with performance of the company because it could be suggested that the rise of this ratio should imply higher performance because of increase of sales revenues.

$$
\text { Acid test ratio }=\frac{\text { Current assets }- \text { Inventory }}{\text { Current liabilities }} \text { (Elliott, B., Elliott, J. 2007: 660). }
$$

Acid test ratio is derived form a current ratio and represents a stricter view on company's liquidity because current assets that cannot be converted into cash quickly as for example inventories or doubtful debts are not contained in this ratio. In this case there are excluded only inventories from current assets. The higher the ratio, the better the ability to repay immediate commitments that the company has.

$$
\text { Debt ratio }=\frac{\text { Total liabilities }}{\text { Total equity and liabilities }} \text { (Sůvová et al. 2000: 104). }
$$

This ratio represents the first and broadest test of indebtedness of the company so that it expresses the relation between the total debt, both current and log-term, and total equity and liabilities of the company. Higher ratio indicates that the company has a higher level of liabilities, which could advance the potential risks for lenders as well as for owners of the company. On the other hand there exists an effect of financial leverage that by higher proportion of liabilities the return on owners' equity will increase.

\section{Key differences between Czech accounting system and IAS/IFRS}

The differences between Czech accounting system and IAS/IFRS could be seen in many areas as for example in different requirements of disclosure and presentation of financial information, in various methods of recognition and measurement of similar items of financial statements. This inconsistency of these two accounting systems flows mainly from their legal status. There exists a strong difference between a continental European philosophy that is based on the Roman law and Anglo-Saxon approach, which applies the common law (D’Arcy 2001).

Czech accounting system represents a national accounting system, which is based on rules that are set direct by Czech state offices or indirect as an implementation of EU directives. General rules are set by the Accounting act No. 563/1991, which specified general requirements for financial accounting and so established a new view on accounting legislation that had been for previous forty years centrally directed by the communist government (Plachá, Hrdý 2007). More detailed requirements are further stated by ministerial regulations and Czech accounting standards that are related to specific groups of accounting entities. Therefore, in this text these documents will be taken into account in the form that is addressed to business units (Vyhlaška č. 500/2002). Besides these accounting rules Czech accounting legislation is strongly influenced by tax law because gross profit determined according to the accounting rules is subsequently used as a basis for calculation of the income tax. Further weakness flows from the absence of a common conceptual framework so that in Czech accounting legislation there is not any comprehensive view on basic accounting concepts for 
preparation of financial statements as well as there are missing any definitions of qualitative characteristics of financial information or description of basic elements of financial statements or requirements for their recognition. If there are any definitions or requirements in Czech accounting legislation, they are mostly in the form of list of explicit items without any economical justifying of their content, so they are not able to provide a relevant guide that should help to prepare financial statements, which can satisfy information needs of the users of financial statements.

On the other hand IAS/IFRS represents a single set of understandable and enforceable global accounting standards that are published by an independent standard setting body (IASB) or by its predecessor International Accounting Standards Committee (IASC) and that were created by using the common law approach. Therefore these standards are not issued in the form of a law but they represent an accounting system that is based on principles (Agoglia et al. 2011). These standards are created especially for listed companies because the use of a single set of understandable and enforceable accounting standards represents an important presumption for effective functioning of financial markets. Some authors, as for example Mládek, talk in the case of IAS/IFRS and US GAAP about financial reporting systems because there systems prescribe what and in which form should be presented in financial statements. On the other hand accounting systems regulate the own accounting procedures (Mládek 2005). IAS/IFRS consists of a common conceptual framework, own international standards and interpretations to these standards. The conceptual framework creates a general ideological foundation for the own standards that should regulate specific areas of financial reporting. The aim of interpretations is to clarify the right application of suitable standards in specific situations or give clear solutions of existing transactions in financial reporting. This system is designed to “...provide information about the financial position, performance and changes in financial position of an entity that is useful to a wide range of users in making economic decisions" (Framework for the Preparation and Presentation of Financial Statements 1989: 12).

The main differences between these two systems could be demonstrated on the example of financial statements that are prepared according to each system. As there will be further analysed only the influence of a different accounting system on balance sheet and subsequently on income statement, there will be mentioned only some key differences in the case of these two statements.

The form of financial statements depends on the different legislative status of each system itself. The Czech legislation prescribes one compulsory vertical pattern of balance sheet and two vertical patterns of income statement whereas expenses could be categorised by nature or by function. Nowadays the first option is used in most cases because it represents more traditional as well as easier one. These patterns of financial statements were implemented according to the optional patterns that are contained in European $4^{\text {th }}$ Directive on Accounting. On the other hand, IAS/IFRS does not determine what pattern of balance sheet or income statement has to be used, so the companies could prepare their statements according to their needs. However, this does not mean that they present the financial statements whatever they want. The companies have to respect the minimum requirements which are determined in the IAS 1, so they don't have to keep a strict order of item presented in financial statements. 
After the amendment of IAS 1 in 2007, which shall be applied for annual periods beginning either on or after 1 January 2009, the term balance sheet was replaced by statement of financial position and income statement was renamed and restructured to statement of comprehensive income that contains besides the original income statement other additional items, which represents gains and losses that influence equity. Within this text there will be used the former names of both statements because they can be also used in this sense for financial statements that are prepared according to the Czech legislation.

Other differences flow from the absence of definitions of basic elements of financial statements and recognition requirements in the Czech legislation against IAS/IFRS. In financial statements according to the Czech legislation could be presented such items that correspond to a list of explicit items that are named and insufficiently "described" in ministerial regulation. To disclose an item according to the IAS/IFRS, the item has to meet the definition of a basic element of financial statements and satisfies the criteria for recognition as well. This causes differences by recognition and measurement of some items according to the Czech legislation and IAS/IFRS because some items that are named in Czech ministerial regulation don't meet the requirements that are requested by IAS/IFRS. It is for example the case of some assets, liabilities, expenses and revenues that will be either different recognised or at least other measured.

\section{Depiction of the selected accounting transactions according to the Czech accounting legislation and IAS/IFRS}

This part deals with the analysis of the influence of a different accounting system on recording of five accounting transactions. Once the requirements of the Czech legislation will be applied and for the second time there will be analysed the impact of using the IAS/IFRS requests. At the end of this part, there will be presented a comprehensive balance sheet and income statement as the summary of the previous five transactions and through the comparison of both financial statements, the overall influence of both accounting systems will be analysed.

To enable an analysis that is more precise, some assumptions have been admitted. When analysing the influence of Czech legislation there will be respected the requirements of accounting legislation, not taxation requirements as for example in the case of depreciation and amortisation, initial or subsequent measurement of items etc. For further simplification of this analysis the question of deferred income tax is omitted. The items in the income statement are analysed by nature not by function, although some authors as for example Mládek does not recommend such a classification of income statement (Mládek 2009). But in this text this classification is used as another simplification and so it should enable higher comparability of income statements because this analysis is mostly used in the Czech Republic (this could be consider as inertia of accounting praxis because this type of analysis was the only possibility in Czech Republic before the year 2003) and IAS/IFRS enable such type of analysis as well. Depreciation and amortization of non-current assets is calculated on the monthly basis with the help of the straight-line method whereas the calculation begins in the month when the item can be firstly used. According to the Czech legislation the company has determined the limit for recognition of non-current assets in the amount of 50,000 Czech crowns (CZK). 
By calculation of implicit interest it is anticipated a quarterly period and for the following transactions there were selected these implicit interest rates. If the trade receivable or payable is collectable in one year the implicit interest rate amounts to $6 \%$ per annum (p. a.) and in the case of two years collection period the implicit interest rate makes $6.5 \%$ p. a. These figures were selected on the basis of the results of the own survey that was made in September 2010 when the banks in the Czech Republic were questioned. The purpose of this survey was to find out the amounts of usual interest rates that are required nowadays in the case of bank credits that are payable within 12 or 24 months. The results of this survey are presented in the following Table 1.

Table 1. Amount of interest rates of bank credits in the Czech Republic

\begin{tabular}{lcc}
\hline \multirow{2}{*}{ Bank } & \multicolumn{2}{c}{ Amount of interest rate in \% p. a. } \\
\cline { 2 - 3 } & one year credit & two years credit \\
\hline Unicredit & min. 6.5 & min. 4.14 \\
\hline Volksbank & $4.25-7.25$ & $4.25-7.25$ \\
\hline ČSOB & $2.20-6.27$ & $3.59-7.79$ \\
\hline Česká spořitelna & about 5.6 & about 5.8 \\
\hline
\end{tabular}

Source: Own survey

In this article, the transactions will be demonstrated on the case of a stock company that was established in the Czech Republic without public subscription of shares. The establishment of this company started during the year 2009 and the date of recording into the Companies Register was on 1 January 2010. To this date there had been signed legal capital in the amount of 5,000,000 Czech crowns (CZK) that was deposited on its bank account. The company is engaged in production and sale of goods.

\subsection{Formation expenses}

According to the Czech legislation formation expenses mean all costs spent on foundation of a company until its legal establishment. These costs encompass especially court and administrative charges, expenses on business trips, broker's commissions, consulting services and rental expenses. All these costs are recognised as intangible asset if the sum of them exceeds the limit that was defined by the company. Otherwise, formation expenses are recognised as expenses for the period. Formation expenses could be amortised over up to five years.

IAS/IFRS allows recognising an item as an asset if it satisfies the definition of an asset that is embodied in the conceptual framework. So this item has to be controlled by the company, it is a result of past events and its economic benefits will flow to the company. Furthermore, the economic benefits associated with this item have to be probable and the cost or value of the item has to be measured with reliability. IAS 38 requires another critical attribute for recognition of an intangible asset that is called identifiability. It means that the intangible asset has to be separable, so it is capable to be sold, transferred, licensed, rented, or exchanged separable and further this intangible asset arises from contractual or other legal rights. So, according to these definitions formation expenses could not be recognised as an intangible asset but they have to be recognised as expenses of the period. 


\section{Illustrative accounting transaction No. 1}

The formation expenses, which have been spent until the date of recording the company into the Companies Register, amount to 120,000 CZK. According to the Czech legislation the formation expenses could have been recognised as an intangible asset because the limit for recognition has been exceeded. The statutory body of the company has decided to amortize this asset over up to five years. The amount of the amortization for the year 2010 makes 24,000 CZK. IAS/IFRS require recognising the formation expenses in amount of $120,000 \mathrm{CZK}$ as expenses of the period. Recognition of formation expenses according to the Czech legislation causes overvaluation of total assets and undervaluation of operating expenses that amounts to $96,000 \mathrm{CZK}$.

\subsection{Depreciation of the purchased machine}

According to the Czech accounting legislation machines and equipment could be recognised as tangible assets if their useful life is longer than one year and their acquisition costs exceed the limit that was determined by the company. Otherwise, they are recognised as inventories. Acquisition costs by purchasing an asset consist of the purchase price of the item and other direct assigned costs as delivery, installation, insurance etc. Assets generally could be depreciated only by their owner and from the year 2009 the companies could use by calculation of depreciation salvage value and method of component depreciation. Because the salvage value and component method are new in the Czech legislation and currently not used by many companies in this text there is used the traditional straight-line depreciation of the whole machine as one object. In this situation Czech legislation further allows to create a provision for reparation of assets if it is expected to repair this asset during its useful life.

IAS/IFRS requires for recognition of the machine as an asset to satisfy the definitions embodied in the conceptual framework as they were described in the previous part of this text and further requirements are set by IAS 16 as for example rules for initial and subsequent measurement. By initial measurement of purchased machines and equipment discounted value has to be used when the payment is deferred. In this case, it has to be used amortised cost method that uses implicit interest rate for discounting the payment to the date of purchase. Cost of purchased asset includes all costs necessary to bring the asset to working condition for its intended use and eventually an initial estimate of the costs of dismantling and removing the item or restoring the location of the item when the useful life of the item has ended. When the asset consists of components that could be recognised separately each component has to be depreciated separately according to its useful life and so provision for reparation is not allowed.

\section{Illustrative accounting transaction No. 2}

On 1 January 2010 the company purchased from its supplier a machine for 3,600,000 CZK that consists of a major part for 2,400,000 CZK and a component for 1,200,000 CZK. These trade payables will have to be paid off on 31 December 2011. Useful life of the major part is 6 years and of the component 2 years. According to the Czech legislation the machine is measured in the nominal value and it is depreciated for 6 years, so the depreciation for the year 2010 amounts to $600,000 \mathrm{CZK}$. Further, there is created a provision for replacement of the component in two years that makes 600,000 CZK each year. According to the IAS/IFRS 
there is used the amortised cost method, so the discounted value of the major part makes 2,115,982 CZK and the component amounts to 1,057,991 CZK. Total depreciation of both components makes $881,660 \mathrm{CZK}$ and further no provision is allowed. The usage of the traditional depreciation method of the machine as one object in the Czech Republic causes overvaluation of total assets by 707,687 CZK and rise of operating expenses by $318,340 \mathrm{CZK}$. On the other hand according to the IAS/IFRS there exists interest expenses for the year 2010 that amounts to $206,309 \mathrm{CZK}$ and liabilities are overall undervalued by $819,718 \mathrm{CZK}$.

\subsection{Revenues of goods sold on credit}

According to the Czech legislation when goods are sold in the whole amount, that is received in cash or is represented in form of trade receivables, it is recognised as revenue at the date when the transaction has occurred. In the case when revenue and the related payment are recognised in different periods the accrual principle has to be used.

IAS/IFRS requires respecting of accrual basis assumption that is embodied in the conceptual framework as well as special requests set by IAS 18. Revenue from the sale of goods shall be recognised recognise only if five special conditions have been satisfied. In the case when the payment is deferred, revenue has to be measured in the discounted value of this amount and further the incurred interest revenue has to be disclosed separately.

\section{Illustrative accounting transaction No. 3}

On 1 July 2010 the company sold goods for 2,120,000 CZK that is payable on 30 June 2011. According to the Czech legislation revenue is recognised immediately to the date of this transaction, so the total assets, short-term receivables as well as revenues are overvalued by $60,874 \mathrm{CZK}$. According to the IAS/IFRS the part of total revenues, exactly the amount of $59,126 \mathrm{CZK}$, represents interest revenue for the year 2010.

\subsection{Cost of the purchased material used in production phase}

Purchased material that is recognised according to the Czech legislation is measured in the amount of the corresponding payment and this amount could eventually include other costs related with the purchase as for example delivery, insurance etc. The consumption of this material could be measured in various methods that are individual purchase prices, FIFO (first-in, first-out) or average costs.

IAS/IFRS requires by initial measurement of inventories to use amortised cost method in the case if deferred payments have occurred. According to IAS 2 the purchased material is measured in the present value of deferred payment and to this amount could be further added cost of conversion and other costs related to bringing the inventories to their present location and condition. Such total measurement base is used for pricing of material used in production as individual cost, FIFO or weighted average cost formula.

\section{Illustrative accounting transaction No. 4}

On 1.October 2010 the company purchased raw material for 1,060,000 CZK that is payable on 30 September 2011. On 20 December this year 75\% of this raw material was used in production phase and this consumption was measured in individual purchase price. Inventory and 
as well as total assets are according to the Czech legislation overvalued by 15,000 CZK and operating income is undervalued by $45,000 \mathrm{CZK}$. The IAS/IFRS requirements causes that short-term trade payables are undervalued by 45,326 CZK that represents deferred interest expense and additionally there is disclosed an interest expense that amounts 14,674 CZK for the year 2010 .

\subsection{Revaluation of the building}

At the end of the period, it has to be examined if the value of the asset has change or not. Czech accounting legislation applies in this case only historical cost model that decrease the value of property, plant and equipment set by initial measurement by cumulated depreciation and cumulated allowances to these items. So there is not allowed to increase the value of the asset even if its market price has increased, although the use of this model in the Czech Republic in some special and very rare cases is permitted (Sedláček, Valouch 2009).

IAS/IFRS permits by subsequent measurement two accounting models that are historical cost model, which is nearly the same as it was described in previous paragraph and revaluation model. If an asset could be measured reliably, it shall be carried at its revalued amount, which is the fair value of the asset less any subsequent accumulated depreciation and subsequent accumulated impairment losses. Revaluation has to be made with sufficient regularity and if it is used the entire class of property, plant and equipment has to be revalued. Strouhal and Židlická suggest implementing the revaluation model in practice in two different ways that consists in the equiproportional increase of initial measurement and accumulated depreciation or in elimination of accumulated depreciation (Strouhal, Židlická 2008: 90). Both ways of recording such transaction influence equity of the company, because there arise a new item in equity that represents revaluation surplus of the given property, plant and equipment.

\section{Illustrative accounting transaction No. 5}

On 1 October 2010 the company acquired building for 5,000,000 CZK that was paid in cash from its bank account. The statutory body of the company decided to depreciate this building for 20 years, so the depreciation for the year 2010 amounts to $62,500 \mathrm{CZK}$. At the end of the year, there was found out that the value of the building raised to 7,000,000 CZK because it was decided to build a new road in the neighbourhood. Because the Czech legislation doesn't allow the revaluation model assets are undervalued by 2,062,500 CZK. By respecting the IAS/IFRS requirements there is used the method that eliminates accumulated depreciation and so in the balance sheet there is recognised an additional item in equity that represents building revaluation surplus in the amount of 2,000,000 CZK.

\subsection{Total influence on balance sheet and income statement}

In this part, there will be made a comparison of balance sheets and income statements whereas once they are prepared according to the Czech legislation and for the second time according to the IAS/IFRS. In the Tables 2 and 3 there is demonstrated a comprehensive influence of the previous five accounting transaction firstly on the balance sheet and secondly on the income statement of the given company. 


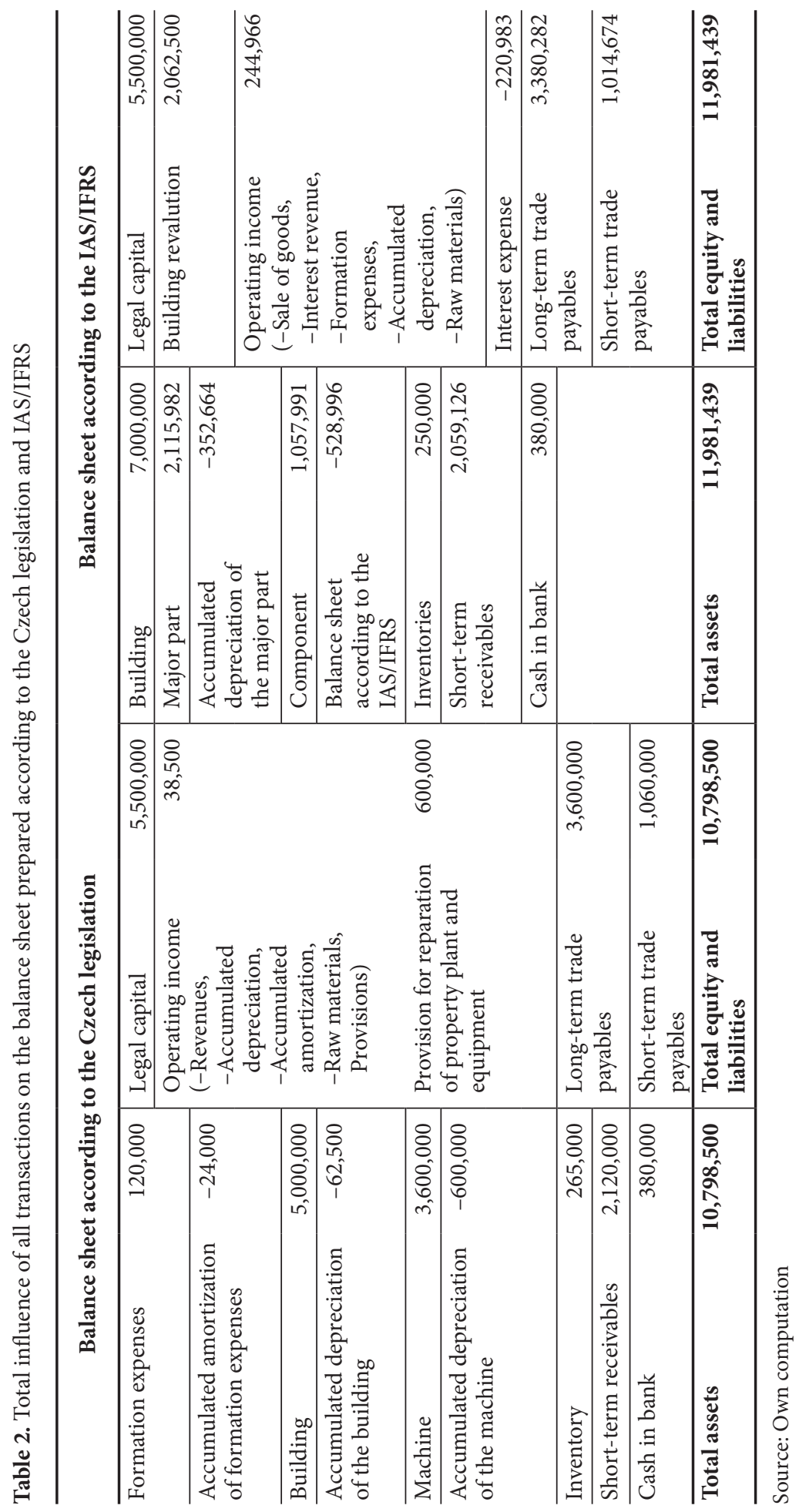


The requirements of Czech legislation have caused, that total assets are undervalued by $1,182,939 \mathrm{CZK}$ and that there exist a different structure of assets as well as of equity and liabilities. It flows mostly from not using the amortised cost model by initial measurement of loans and receivables and from different rules used by calculation of depreciation and amortization of assets and as well as by recognition of non-current assets. The impact of these requirements that have caused overvaluation of assets has been outbalanced by the influence of the building revaluation surplus that has been recognised according to the IAS/IFRS.

Table 3. Total influence of all transactions on the income statement prepared according to the Czech legislation and IAS/IFRS

\begin{tabular}{lrlr}
\hline $\begin{array}{c}\text { Income statement according to the } \\
\text { Czech legislation }\end{array}$ & \multicolumn{2}{c}{$\begin{array}{c}\text { Income statement according to the } \\
\text { IAS/IFRS }\end{array}$} \\
\hline Revenues - sale of goods & $2,120,000$ & Revenues - sale of goods & $2,000,000$ \\
\hline - Raw materials & $-795,000$ & Revenues - interest revenue & 59,126 \\
\hline - Accumulated amortization & $-24,000$ & - Raw materials & $-750,000$ \\
\hline - Accumulated deprecitation & $-662,500$ & - Accumulated deprecitation & $-944,160$ \\
\hline - Provisions & $-600,000$ & - Formation expenses & $-120,000$ \\
\hline Operating profit (EBIT) & 38,500 & Operating profit (EBIT) & 244,966 \\
\hline & & - Interest expense & $-220,983$ \\
\hline Profit before tax & 38,500 & Profit before tax & 23,983 \\
\hline
\end{tabular}

Source: Own computation

Different accounting requirements have caused that operating profit according the IAS/IFRS is overvalued by 206,466 CZK and so it is about 6.4 times higher than in the case when Czech legislation is applied. The structure of the income statement is different as well for example there are separately disclosed interest expenses. These differences have been caused by the same reasons that were discussed in the previous paragraph.

\section{Comparison of financial ratios}

In this part, there will be calculated the selected financial ratios that have been described in the part one. As the input data there are used the amounts from the balance sheets and the income statements that are presented in the following part. Each of these four ratios is computed twice because there is used input data worked out on the basis of different accounting system. So the results of the four selected ratios, which are calculated once according to the Czech legislation and for the second time according to the IAS/IFRS, are comprehensive presented in the Table 4 .

In the previous table, there could be seen that the profitability measured by the first ratio is about eight times higher when IAS/IFRS is applied than in the case of use of the Czech legislation. This is mostly due to the difference of the amount of EBIT because the operating profit calculated according to the Czech legislation is about 6.4 times lower than according to the IAS/IFRS. The highest influence on EBIT have operating expenses because their amount recognised according to the Czech legislation is by about 15\% higher than if IAS/IFRS is used. 
Table 4. Financial ratios calculated on the basis of a different accounting system

\begin{tabular}{lcc}
\hline \multicolumn{1}{c}{ Financial ratio } & Czech legislation & IAS/IFRS \\
\hline Return on capital employed & 0.0073 & 0.0557 \\
\hline Asset turnover ratio & 0.1963 & 0.1669 \\
\hline Acid test ratio & 2.3585 & 2.4039 \\
\hline Debt ratio & 0.4871 & 0.3668 \\
\hline
\end{tabular}

Source: Own computation

This is caused by recognition of provision for reparation of property plant and equipment and by not separating interest expenses which are excluded from EBIT according to the IAS/IFRS.

The asset turnover ratio is not high in both cases because the amount of sales is low in relation to the total assets. In the case of the Czech legislation the asset turnover ratio is a bit higher than if IAS/IFRS is used which is caused by lower amount of total assets and higher amount of revenues. In this case the impact of revaluation of the building according to the IAS/IFRS has been higher than the influence of the recognition of formation expenses and not excluding of interest expenses from the purchasing price of assets according to the Czech legislation in the case of the deferred payment.

The third ratio shows a little better result in the case of IAS/IFRS that flows mainly from the amount of short-term liabilities that is higher by about $4.5 \%$ according to the Czech legislation. Beside this, there exists a similar relationship by short-term receivables as well as by inventories that are according to the Czech legislation higher than if IAS/IFRS is applied. All these differences are caused by not using the amortised cost method by initial measurement of loans and receivables, if the payment is deferred.

According to the last ratio the indebtedness of the company is by 12 percentage points higher when the Czech legislation is applied. This is caused by the higher amount of total liabilities recognised according to the Czech legislation in interaction with the lower sum of total equity and liabilities. This high amount of liabilities was mostly caused by not using the amortised cost method by initial measurement of liabilities and as well as by recognition of the provision for reparation of property plant and equipment. The higher amount of total equity and liabilities was due to the additional item in equity that represents the building revaluation surplus.

\section{Conclusion}

In this article there has been examined if and eventually how significantly the recording of accounting transactions according to the Czech accounting legislation and to the IAS/IFRS is able to change the results of four selected financial ratios that describes key features of financial management of the company. The contribution of the authors consists in creating a currently unpublished model confirming that there exist differences between the Czech accounting legislation and IAS/IFRS. These differences influence the amounts of items that are disclosed in financial statements especially in the balance sheet and income statement. Dissimilarities in input data have caused different results of the four selected financial ratios. The highest 
difference has been detected by return on capital employed ratio and by debt ratio, while the results of asset turnover ratio and acid test ratio have not shown significant differences. This is caused mostly by selection of the described accounting transactions that have influenced especially the amount of operating profit and the composition of equity and liabilities, while the differences in initial measurement of assets have not been significant (Speth et al. 2010). In the case of asset turnover and acid test ratio the own construction of the ratio diminish the differences because separation of interest influence both parts of the fraction.

In this context it could be suggested that the results could be more different if there would be analysed more accounting transactions not only one transaction of each type. In the case of disclosure of interest expenses or revenues according to the IAS/IFRS the higher differences could be found out if the payments would be deferred for a longer time. Further, it is necessary to mention that there exists accounting transactions that influence the individual items as well as the total amount of assets or equity and liabilities in an opposite way. Such a situation is represented also in this text when the building revaluation surplus recognised according to the IAS/IFRS has exceeded the impact of recognition of formation expenses and higher initial measurement of assets that has been calculated according to the Czech legislation. Further, it could be interesting to examine how the structure of financial statements would change if some larger company which would have larger amounts of the selected transactions were analysed. It means, if it changed only the absolute amounts of the items in financial statements or if there were even found any significant changes in results of the selected ratios.

\section{References}

Agoglia, C. P.; Doupnik, T. S.; Tsakumis, G. T. 2011. Principles-based versus rules-based accounting standards: the influence of standard precision and audit committee strength on financial reporting decisions, Accounting Review 86(3): 747-767. http://dx.doi.org/10.2308/accr.00000045

Alexander, D.; Nobes, C. H. 2004. Financial Accounting. An International Introduction. Harlow: Prentice Hall. D'Arcy, A. 2001. Accounting classification and the international harmonization debate - an empirical investigation, Accounting Organizations and Society 26(4-5): 327-349. http://dx.doi.org/10.1016/S0361-3682(00)00036-2

De Franco, G.; Kothari, S. P.; Verdi, R. S. 2011. The benefits of financial statement comparability, Journal of Accounting Research 49(4): 895-931. http://dx.doi.org/10.1111/j.1475-679X.2011.00415.x

Elliott, B.; Elliott, J. 2007. Financial Accounting and Reporting. Harlow: Prentice Hall.

Framework for the Preparation and Presentation of Financial Statements [online]. 1989. Available from Internet: http://eifrs.iasb.org/eifrs/bnstandards/en/framework.pdf

IAS 1 - Presentation of Financial Statements [online]. 2007. Available from Internet: http://eifrs.iasb.org/ eifrs/bnstandards/en/ias1.pdf

IAS 16 - Property, Plant and Equipment [online]. 2003. Available from Internet: http://eifrs.iasb.org/eifrs/ bnstandards/en/ias16.pdf

IAS 18 - Revenue [online]. 2001. Available from Internet: http://eifrs.iasb.org/eifrs/bnstandards/en/ias18.pdf IAS 2 - Inventories [online]. 2003. Available from Internet: http://eifrs.iasb.org/eifrs/bnstandards/en/ias2.pdf

IAS 38 - Intangible Assets [online]. 2004. Available from Internet: http://eifrs.iasb.org/eifrs/bnstandards/ en/ias38.pdf 
Ingram, R. W.; Albright, T. I. 2007. Financial accounting: Information for Decisions. Mason: Thomson South-Western.

Kovanicová, D.; Kovanic, P. 1995. Poklady skryté v účetnictví. Díl II. Praha: Polygon.

Lev, B.; Li, S.; Sougiannis, T. 2010. The usefulness of accounting estimates for predicting cash flow and earnings, Review of Accounting Studies 15(4): 779-807. http://dx.doi.org/10.1007/s11142-009-9107-6

McLeaney, E.; Atrill, P. 2005. Accounting: an Introduction. Harlow: Prentice Hall.

Mládek, R. 2005. Světové účetnictví. Praha: Linde.

Mládek, R. 2009. Postupy účtování podle IFRS. Praha: Leges.

Nobes, C.; Parker, R. 2006. Comparative International Accounting. Harlow: Prentice Hall.

Petřík, T. 2009. Ekonomické a finanční rízení firmy. Praha: Grada.

Plachá, D.; Hrdý, M. 2007. Analýza historického vývoje účetnictví v Českých zemích v letech 1918-2006, E\&M Ekonomie a Management 10(2): 65-73.

Sedláček, J.; Valouch, P. 2009. Reálná hodnota v cenové regulaci přirozeného monopolu, E\&M Ekonomie a Management 12(2): 6-14.

Speth, H.; Šebo, J.; Kováč, J. 2010. How can companies actively redound to improve their ratings? A current bank survey, E\&M Ekonomie a Management 13(4): 86-95.

Strouhal, J.; Židlická, R. 2008. Účetnictví 2008. Brno: Computer Press.

Sůvová, H.; Srpová, J.; Poloprutská, R.; Petr, J.; Knaifl, O.; Kohout, P.; Jacko, F.; Hubálek, K.; Špaček, E. 2000. Finanční analýza v ř́zení podniku, v bance a na počítači. Praha: Bankovní institut.

Užik, M.; Šoltés, V. 2009. Vplyv zmeny ratingu na ceny spoločností obchodovaných na kapitálovom trhu, E\&M Ekonomie a Management 12(1): 49-56.

Vance, D. E. 2002. Financial Analysis and Decision Making. New York: McGraw-Hill.

Vyhláška č. 500/2002 Sb., pro účetní jednotky, které jsou podnikateli účtujícími v soustavě podvojného účetnictví.

Wahlen, J. M.; Wieland, M. M. 2011. Can financial statement analysis beat consensus analysts' recommendations?, Review of Accounting Studies 16(1): 89-115. http://dx.doi.org/10.1007/s11142-010-9124-5

Olga MALÍKOVÁ obtained her master degree in Economics and management of light industry from the Textile Faculty and her Ph.D. in Economics and management of enterprise from the Faculty of Economics, the Technical University of Liberec. Since the year 1996 she has been working as a lecturer at the Department of Finance and Accounting at the Faculty of Economics, the Technical university of Liberec. Her research is focused on financial accounting of enterprises and insurance companies, evolution of the discipline and current harmonisation process of accounting systems. Actively she participates in international conferences with contributions of the topics relating to financial accounting. She is author or co-author of three monographs. Periodically she acts as visiting lecturer at universities abroad. She is board member of Higher Education Development Fund and its internal reviewer of submitted projects.

Zdeněk BRABEC obtained his Ph.D. in Economics and management from the Technical University of Liberec. He is currently working as a lecturer at the Department of Finance and Accounting at the Faculty of Economics at the Technical university of Liberec. His research is focused on financial accounting and harmonisation of accounting systems. His articles were published for example in Journal Acta academia karviniensia. 